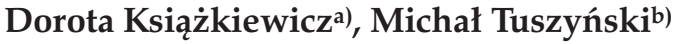

a) Faculty of Economics, University of Gdansk, Poland

https://orcid.org/0000-0002-8751-819x

b) Port of Gdynia

\title{
INTEGRATING CORE MARITIME PORTS IN GDYNIA AND KOPER WITH TENT-T BALTIC -ADRIATIC CORRIDOR INFRASTRUCTURE
}

\begin{abstract}
Maritime ports are key elements of transport TEN-T system. As the volume of cargo processed by ports in TENT-T network is rising, it is necessary develop ports' infrastructure to accommodate rising cargo flows. Gateway ports as Gdynia or Koper seize the opportunity to become more competitive by adapting to international infrastructure standards. The precondition for existence and for successful development of a port is to offer seamless connection with the hinterland and overseas markets, therefore both ports have been putting effort in developing ports' infrastructure along with hinterland and overseas connections. The goal of the article is to analyse the trends infrastructure development in gateway ports of Gdynia located in the Baltic-Adriatic TENT-T transport corridor and their plans for further integration with the core TENT-T network.
\end{abstract}

Keywords: maritime ports, TEN-T, TEN-T network, Baltic-Adriatic corridor, transport infrastructure, transport policy

JEL: R42

\section{Introduction}

According to the White Paper - Roadmap to a Single European Transport Area, prepared and published in 2011 by the European Commission as a strategic document on transport policy in the EU, functioning and development of transport system is of paramount importance for the European economy and society. It enables prosperity, growth and creates jobs in numerous economic branches. 
One of the key objectives within the EU transport strategy is to unite markets and societies by mitigating barriers between modes and national transport systems. Creating a coherent and effective system can be forged by means of core network of corridors, enabling the soaring and consolidated volumes of both passengers' and cargo traffic. The core network should deploy new technologies in transport and logistics, multimodal combination of modes, high standard of infrastructure and meeting with environmental challenges and modern transport policy trends, i.e. decoupling and shift paradigms (White Paper "Roadmap to a Single European transport Area -Towards a competitive and resources efficient transport system). The Connecting Europe Facility (CEF) is a flagship funding programme supplying targeted investments across with a key role in supporting the European Commission's priorities related to smart, sustainable and inclusive growth that has been deployed for transport infrastructure development among other goals (European Commission, 2019).

Maritime ports create value and are a source of the comparative advantage to national economies. Therefore they are an important component of Ports of Gdynia and Koper are middle-sized gateway ports located on the coasts of Poland and Slovenia, both being landmarks in Baltic-Adriatic Transport Corridor.

\section{Methodology and theory}

When analysing the level and structure of infrastructure investments in ports of Gdynia and Koper, the desk research method was used, which involved analysing, verifying, and merging existing data and information from EU sources, statistics and publications, together with information provided by port authorities.

The collected material was ordered and presented in the form of a summary. The paper can be used as a road map to understand the importance of cross-border infrastructure development strategy.

\section{Results}

The most important conclusions include:

- gateway ports of Gdynia and Koper have been in need of specific infrastructure investments to be able to adapt to a growing cargo throughput,

- within the framework of EU transport policy, the infrastructure development in gateway ports need address specific local needs,

- thanks to CEF Transport funding important improvements have already been made, or are expected to be made, in particular with regard to rail transport. Rail Actions on the corridor are expected to address existing bottlenecks and improve infrastructure quality and standards, especially regarding speed, axle load and train length as well as safety.

- the level of ports' connectivity reflects on the overall performance of Baltic-Adriatic corridor, by lowering transport costs and enabling shorter transit times. 


\section{TEN-T Policy approach}

The idea of Trans-European Transport Network was established to create and implement measures of effective and sustainable transport development across the EU.

The EU's transport network (TEN-T) policy recognises the importance of a strategic and holistic approach for the development of a European network of transport infrastructure. The TEN-T comprises a dual layer structure in which the comprehensive network ensures connectivity of all regions of the EU whereas the core network consists of nodes of the network which are of the highest strategic importance for the EU. By means of European Commission planning methodology, those nodes include urban nodes, ports and airports, as well as border crossing points. In practical terms, those are nodes where local, regional and international traffic concentrate The TEN-T Regulation 1315/2013/EU defines legally binding targets for its infrastructure aims, with the core network to be implemented by 2030 and the comprehensive network by 2050. The development of the comprehensive network include, among others:

- ensuring accessibility and connectivity for all regions of the Union;

- ensuring optimal integration of the transport modes and interoperability within transport modes;

- bridging missing links and removing bottlenecks, particularly in cross-border sections;

- improving or maintaining the quality of infrastructure in terms of safety, security, efficiency etc.;

- deploying telematic applications and promoting innovative technological development.

The TEN-T Regulation also establishes nine core network corridors (CNC) which are a further instrument by which to facilitate the coordinated and timely implementation of the core network. According to TEN-T legal act, the major objective of this 'corridor approach' is to establish interconnections and interoperability between national transport systems in a resource-efficient way. It means securing connections between different elements of infrastructure, for example maritime ports with its hinterland and foreland. It is worth stressing that TEN-T network consists of existing infrastructure but should be developed through upgrading of existing infrastructure and through measures promoting its resource-efficient use (Regulation (EU) No 1315/2013 of the European Parliament and of the Council of 11 December 2013 on Union guidelines for the development of the trans-European transport network and repealing Decision No 661/2010/EU).

Ensuring multimodality within the core network can be achieved by completion of missing links in the network, especially upgrading infrastructure in cross - border sections and bottlenecks. 'Cross-border section' means the section which ensures the continuity of a project of common interest between the nearest urban nodes on both sides of the border of two Member States or between a Member State and a neighbouring country; 'bottleneck' means a physical, technical or functional barrier which leads to a system break affecting the continuity of long-distance or cross-border flows and which can be surmounted by creating new infrastructure or 
substantially upgrading existing infrastructure that could bring significant improvements which will solve the bottleneck constraints (Regulation (EU) No 1315/2013). The TEN-T Regulations require and promote a certain infrastructural standard of the network, ensuring cohesion within transport systems and integration of transport modes in terms of multimodality. Table 1. depicts infrastructure standards in order to provide sufficient capacity in the future common EU transport area.

Regarding maritime transport, its priorities has been set in TEN-T guidelines and refer to (EU Regulation, 2013):

- motorways of the sea including short-sea shipping, facilitating the development of hinterland connections and developing, in particular, measures to improve the environmental performance of maritime transport;

- interconnection of maritime ports with inland waterways;

- new technologies and innovation for the promotion of alternative fuels and energy-efficient maritime transport;

- modernisation of the infrastructure necessary for transport operations within the port area.

In practical terms, the EU maritime policy focuses on ports and motorways of the seas (MoS). The ports are considered entry and exit points for the land infrastructure of the comprehensive network. Whereas motorways of the seas epitomise the maritime dimension of TEN-T and consist of, aside the ports, short-sea shipping, infrastructure, equipment, freight terminals, logistics platforms, ICT and procedures enabling operating between at least two ports, including hinterland connections.

Ports are in fact gateways for whole future European single transport area. TEN-T indicate 328 ports of utmost importance (for instance, five in Poland - Gdansk, Gdynia, Szczecin, Swinoujscie and Police and only one in Slovenia - Koper). The long - term challenge is to perform across the board since ports service not only cargo handling, but also its hinterland, foreland and catchment area within or in - between core network corridors (European Commission, 2014). In keeping with TEN-t sectoral strategy for Motorway of the Sea (MoS13), integrating door-to-door logistics chain can be achieved by improving maritime ports last-mile connections by rail and road and inland waterway not only by constructing physical infrastructure, but also by utilising related ICT to connect the different modes of transport present at a port (European Commission, 2018). 


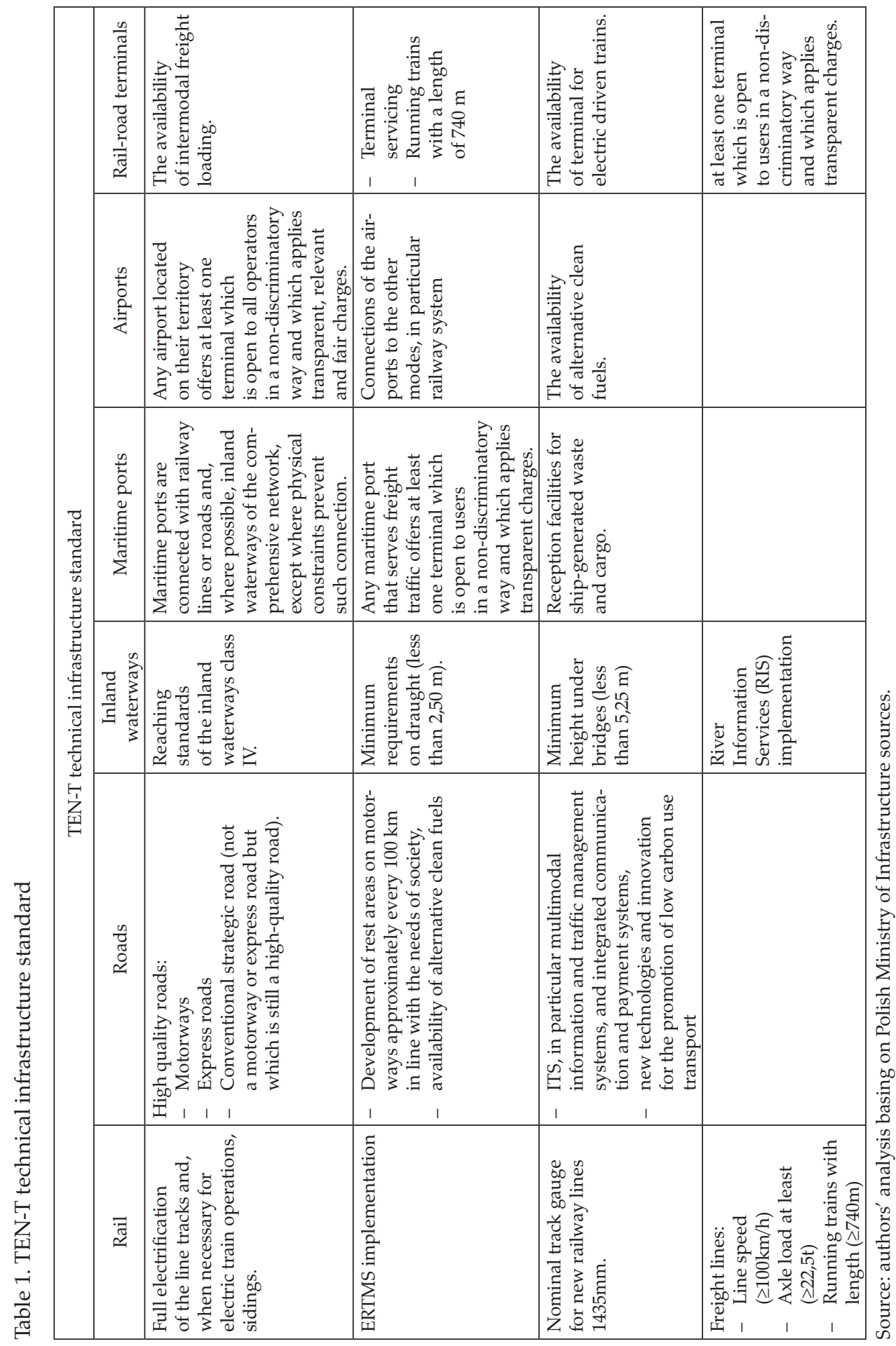




\section{Significance of maritime port's hinterland and supply chain integration}

Maritime ports hinterland is regarded as a crucial factor effecting nowadays port's competitiveness. In fact, the amount and extent of cargo handled outside the port area, within the logistic supply chain, creates an added in terms of cost efficiency, reduced time and reliability of partners involved in the logistic process. In light of analytical insights as well as economic practice, five efficient hinterland conditions can be distinguished:

- sufficient capacity of the hinterland and in the interface between port and hinterland infrastructure;

- efficient use of hinterland infrastructure in terms of coordination;

- coordination and cooperation within the transport chain;

- sustainability from an environmental point of view;

- attractive services (price and quality) of the service providers in the transport chain (terminal operators, carriers, etc.) (Merk, Notteboom, 2015).

TEN-T policy providing by means of European CNC Coordinators and Rail Freight Corridors cooperation is somewhat an instrument enacting port extended gateway concept. The EU documents endorse the changing role of maritime ports in logistics. In recent years, ports focussed on administrative issues, port's infrastructure development and capacity enhancement. Currently, ports have to meet the global transport and logistics challenges, i.e. growing demand for container transport and larger vessels' supply trend and imbalance in container flows from regional perspective. Hence, concentrating on connectivity between the port and its hinterland through various intermodal transport modes is required. The contemporary role of port authorities will be to act as facilitator and integrator in logistics chains by:

- optimising and enhancing port services and infrastructure (foreland and hinterland);

- creating platforms with all stakeholders to address issues affecting logistics performance;

- promoting efficient intermodal transport system in order to develop strategic relations with the hinterland (European Parliament, 2008).

Connecting ports to land-based transport is a critical factor for port competitiveness. Bottlenecks in ports and their hinterland cause congestion which generate negative external costs. Efficient rail, road and inland waterway connections can reduce congestion by providing mass transport. Ports also consolidate cargo into volumes suitable for trains or barges, which makes intermodal solutions commercially viable in terms of being alternative in long distance road transport (European Commission, 2015).

In fact, maritime ports activities in logistic supply chains are triggered by external trends. It influences ports' investment policies in order to meet global challenges, such as: trends in maritime industry (vessels size increasing, alliances), decarbonisation, digitalisation, automation, security in transport, cities' expansion in the hinterland and quality of life agenda etc. In other words, there is a need 
for developing new or modernising infrastructure than increasing the capacity of the existing one. According to a research, $65 \%$ of investment projects launched by the EU ports, refer to basic port infrastructure, marine access and transport - related hinterland investments (rail, road, inland waterways connections). Hence, by enhancing connectivity with its hinterland and the wider economy, ports as European gateways, especially within TEN-T core network, create a cross-border added value of international significance. It's worth underlining that the predominant share of freight handled in European ports represent international context. In the upcoming decade, the ports opt for continuing their investment plans, both in terms of hinterland and intra - port connections. It is highly recommended to strengthen maritime ports' role as multimodal nodes in logistic chains in EU transport policy (ESPO, 2019).

According to Annex II of 1315/2013 Regulation (list of nodes of the core and comprehensive network), both maritime ports Gdynia and Koper are regarded as core maritime ports in TEN-T Baltic - Adriatic Corridor. It's worth mentioning that this corridor crosses six Member States (Poland, Czech Republic, Slovakia, Austria, Italy and Slovenia), the corridor connects the Baltic ports of Gdynia/Gdańsk and Szczecin/Świnoujście with the ports in the Adriatic basin, including the Port of Koper. Figure 1. presents the beginning/end points of the corridor starting in Gdynia and ending in Koper.

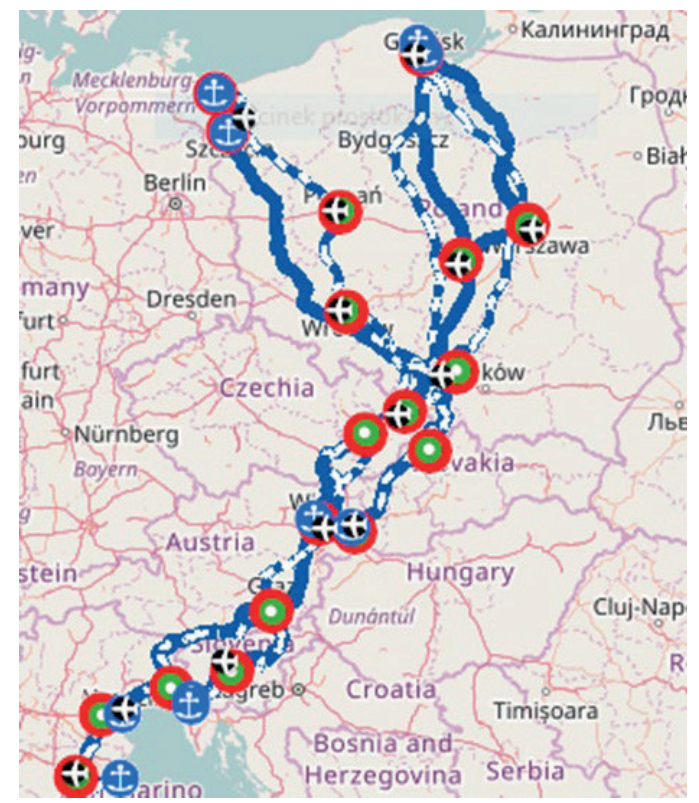

Figure 1. TEN-T Baltic - Adriatic Corridor with its gateway ports in Gdynia (Baltic Sea) and Koper (Adriatic Sea)

Source: TENTec Interactive Map Viewer 


\section{Economic potential and last mile connections of the core maritime port of Gdynia}

Port of Gdynia stands for TEN - T core element in Gdynia transport node and entry/exit point in Baltic - Adriatic Corridor. It is a multitasking port and one of the leading ones in Baltic Sea Region. It specializes in general cargo handling, predominantly unitised cargo transported in ro-ro and container technologies. A significant role in the port's activity is played by 10 well - equipped terminals, used by largest shipping operators. The Port of Gdynia links maritime routes with Polish and European rail network via well - developed network of regular ro-ro, ferry and container connections. The railway links form the European Freight Corridor No. 5, the road connections of E-75 and E-77 have the European status, while the maritime stretches compose short sea shipping connections with many Baltic ports as well as an important Motorway of the Sea (MoS) between the ports of Gdynia and Karlskrona. At the same time, Gdynia serves as a key node where the last mile TEN-T corridor infrastructure mixes with the infrastructure for regional and local traffic (TENTacle Project, 2019a). As stated in the TEN-T Guidelines, in nodes seamless connection should be ensured between the two subsets of infrastructure. However, no guidance has been issued how to achieve that. Neither is advice available how to combine it with the need to improve accessibility and multimodal capacity of the TEN-T core seaport in the context of dynamically growing volumes. The current last mile access networks are not able to carry the flows, forecasted to almost double in 2027, and nearly triple in 2045 This threatens Gdynia port's capability to long-term serve supply chains in the global and the Baltic trade dimensions (TENTacle project, 2019b). The cargo volume handled in years 2015 - 2018 in the Port of Gdynia is depicted in Figure 2.

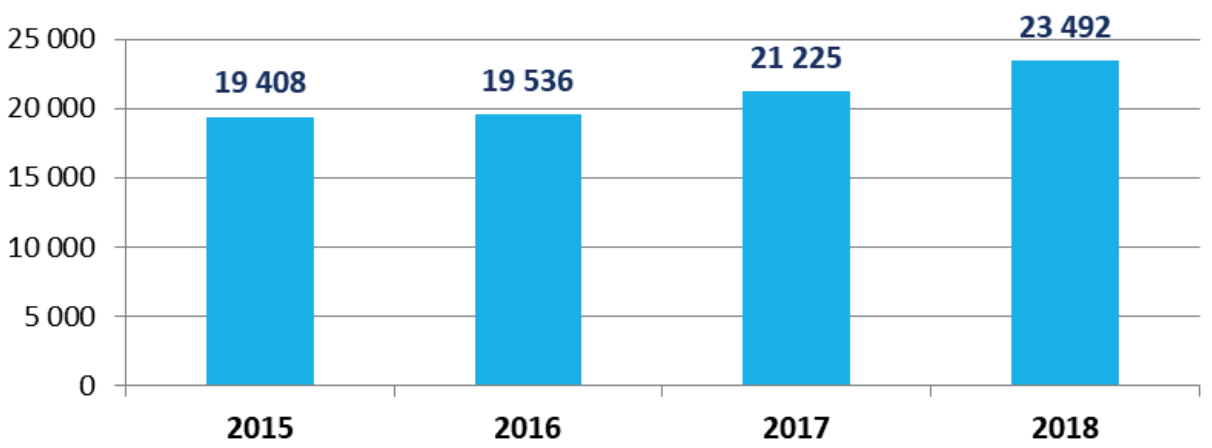

Figure 2. The cargo volume handled in years 2015 - 2018 in the Port of Gdynia (in tons) Source: Port of Gdynia Authority S.A

Volumes handled in the port are rising and challenging the port facilities capacity and accessibility. Figure 3 presents structure of cargo in the Port of Gdynia in 2018. General cargo has the largest share. Figure 4. shows TEU handled by terminals in the Port of Gdynia in years 2015 - 2018. 


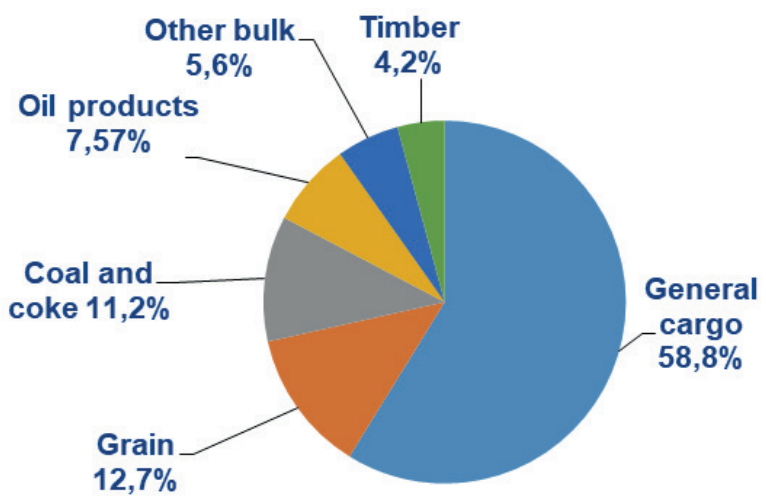

Figure 3. Structure of cargo in the Port of Gdynia in 2018 (in \%)

Source: Port of Gdynia Authority S.A.

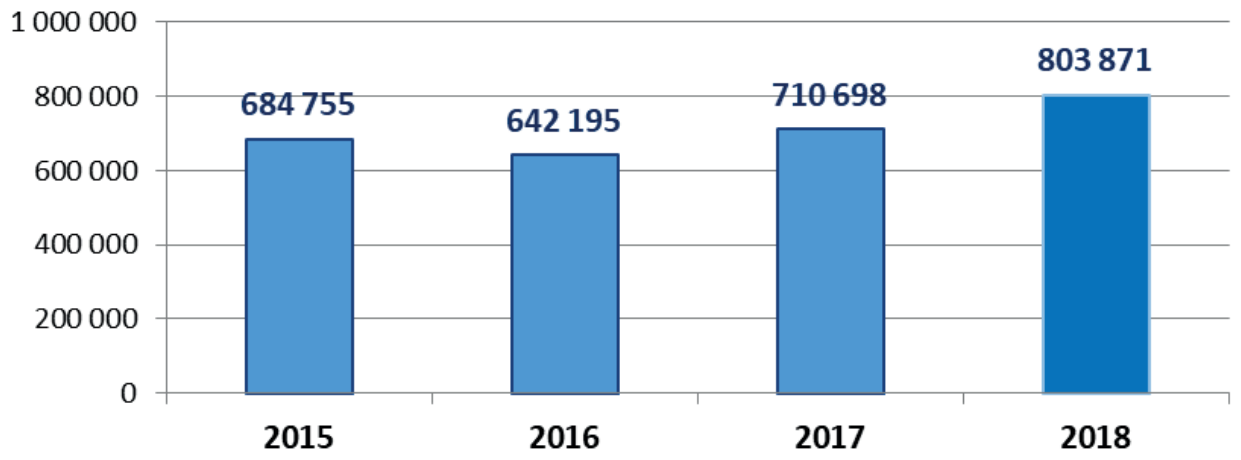

Figure 4. The cargo volume handled in years 2015 - 2018 in the Port of Gdynia (TEU) Source: Port of Gdynia Authority

In 2018, TEU cargo handled in the port reached 803871 and increased by $15 \%$ in relation to 2015 (684 755 TEU). Currently, three terminals service container traffic in the port: Hutchison Port Gdynia, Baltic Container Terminal (BCT) and OT Port. Figure 5. presents modal shift in cargo handlings in the Port of Gdynia in years 2015 - 2018. 


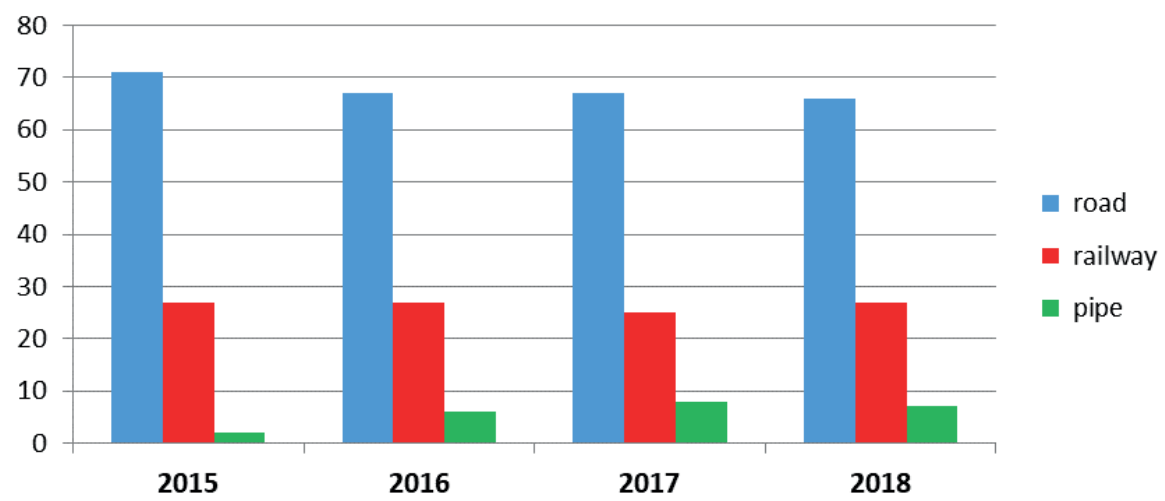

Figure 5. The cargo handlings in the Port of Gdynia in years 2015 - 2018, modal split (in \%) Source: Port of Gdynia Authority

Road transport is the dominant transport mode se in the port's hinterland. Unfortunately, the existing transport infrastructure does not meet the TEN-T standards. The essential challenge is to connect the existing logistic and transport infrastructure with other core network elements within TEN - T, allowing the seamless, safe and sustainable mobility of persons and goods, ensuring accessibility and connectivity. Improvements to respond to capacity expansion needs in in Gdynia are:

- within rail transport, works for the improvement of the standards of the railway lines interconnecting the terminals to the main lines 202 and 201 belonging to the Baltic-Adriatic Corridor are required;

- critical issues exist in the road network providing access to the port. The actions addressing the road bottlenecks which may be implemented by 2030 are: reconstruction of Kwiatkowski viaduct, construction of Droga Czerwona and upgrading of Polska Street and Janka Wiśniewskiego Street (European Commission, 2018b).

In 2018 the Polish Supreme Audit Office, published a report on the results of the inspection regarding "Access infrastructure to Polish seaports". The report emphasizes the barriers and difficulties of road and rail access to the Port in Gdynia and recommends the Polish State to implement the requirements stipulated in the TEN-T regulation establishing guidelines for the development of the TEN-T network (NIK, 2018). The road access has to comply with TEN-T requirements $-11,5$ ton axle-load capacity and standards of the high-quality roads, as stipulated in article 17 of the EU Regulation no 1315/2013. The main administrative barrier in the development of the BA Corridor infrastructure in Gdynia transport node is that the "last mile" access roads to the port of Gdynia are the municipal roads, not administered by GDDKiA (General Directorate for National Roads and Highways) and thus at this moment do not meet TEN-T standards. Therefore, their implementation require that GDDKiA will take over the responsibility for their execution and administration.

In the light of 1316/2013 Regulation establishing the 'Connecting Europe Facility' financial instrument accelerating investments in TEN-T networks and identifying 
projects of common interest, core nodes such as Gdynia maritime port has to have a direct connection (interconnections) to the network. Such transport links can be implemented by 'removing bottlenecks, enhancing rail interoperability, bridging missing links and, in particular, improving cross-border sections' (article 4 of the Regulation). As seen in figure 6 Gdynia core maritime node is not considered as a cross - border section.

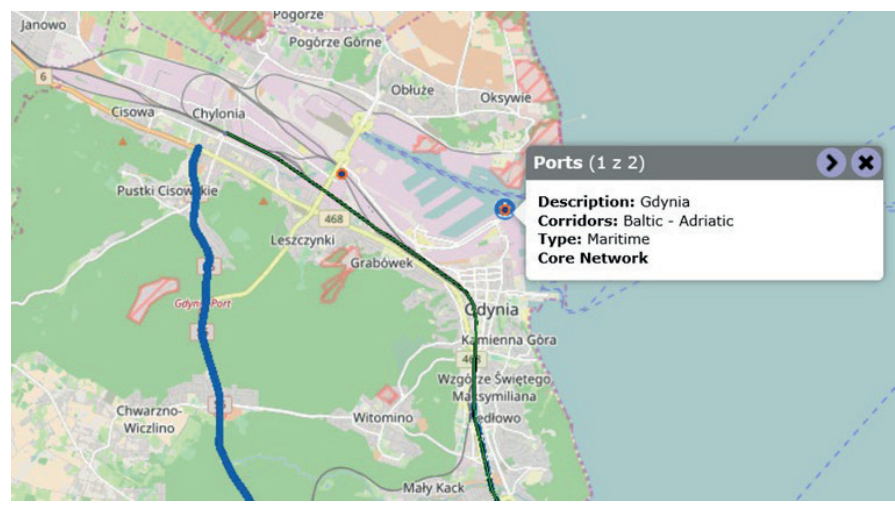

Figure 6. Gdynia core node last mile (TEN-T)

Source: TENTec Interactive Map Viewer

Currently, the only direct connection to the core port is Kwiatkowski Viaduct which is highly insufficient. Figure 7 and 8 depict the exact road and rail missing links in Gdynia.

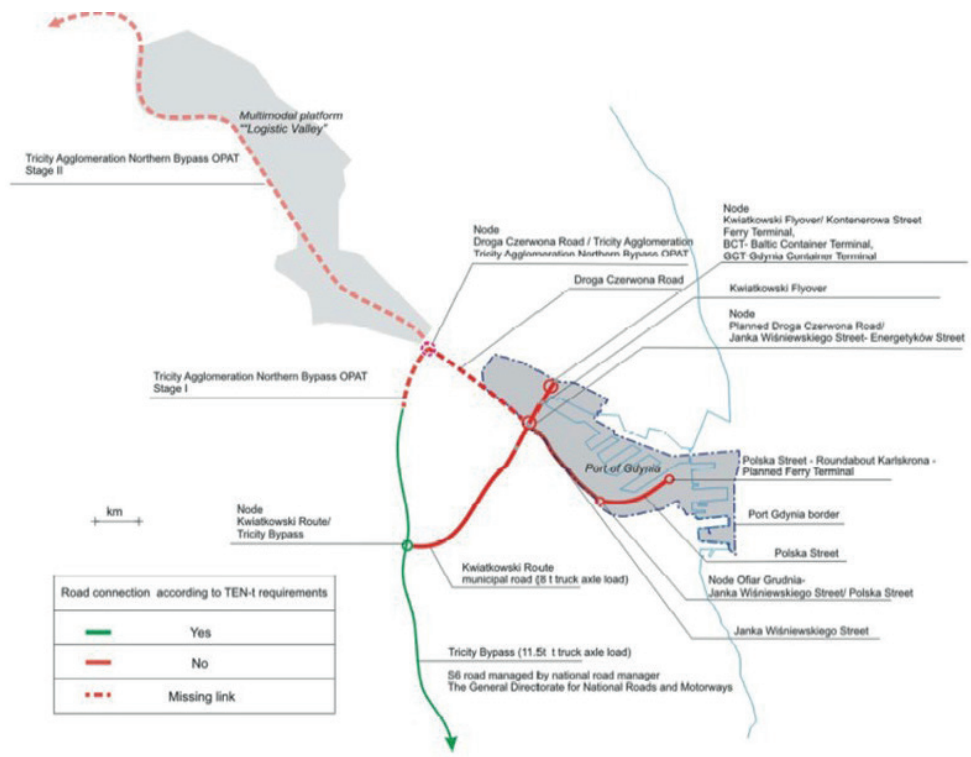

Figure 7. Missing road links in Gdynia Core maritime port Source: Port of Gdynia Authority S.A. 


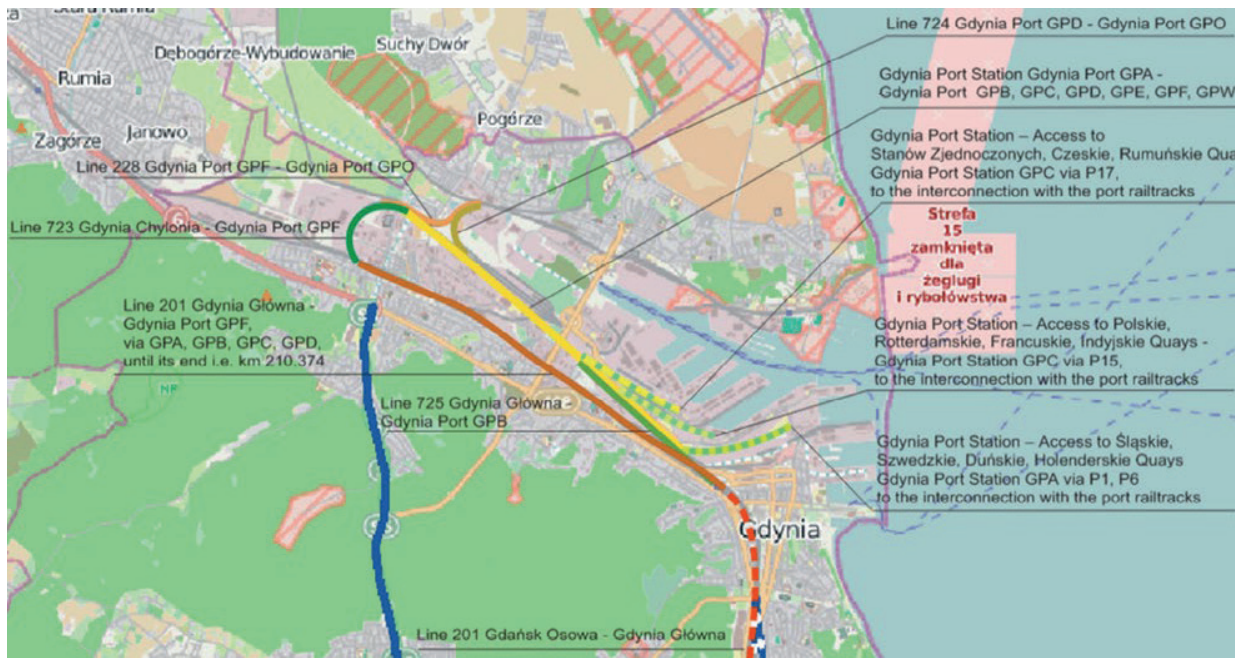

Figure 8. Missing rail links in Gdynia Core maritime port

Source: Port of Gdynia Authority S.A.

\section{Economic potential and last mile connections of the core maritime port of Koper}

Port of Koper, the only port in Slovenia, is situated on the shore of the Gulf of Koper in the northern Adriatic Sea. It is the point of intersection of two important corridors: the Baltic-Adriatic corridor and the Mediterranean corridor. As part of the Baltic-Adriatic Transport Corridor, Port of Koper offers logistic services and transhipments of cargo mainly on routs covering markets of Central and Southeast Europe and the Mediterranean Sea and Far East. Luka Koper d. d., Port and logistic system is a public limited company which develops and manages the Port of Koper. The company operates 12 specialized terminals in the multipurpose port, handling and warehousing of all types of cargo: containers, cars and Ro-Ro, various general cargo products, dry bulk, liquid bulk and passengers. Luka Koper is also a member of the North Adriatic Ports Association the NAPA. The main competitive advantage of the Port of Koper is that it offers the shortest sea route from the Far East to Central and Eastern Europe. There is a network of marine routes consisting of over 130 destinations, operated by numerous shipping lines. The port was ranked $80^{\text {th }}$ out of 900 assessed container ports in the United Nations Conference on Trade and Development (UNCTAD) annual list of the best-connected container ports (UNCTAD, 2019). The calculation for an individual port in the list is mainly based on the number and frequency of connections with other ports as well as on the size of the ships sailing to the port. The amount and frequency of cargo handling of individual ships plays an important role when estimating the port's area of influence. A higher number of destinations and frequency of connections offers clients a wider choice when planning the most optimal logistics solutions. 
There are efficient rail and road intermodal connections from the port of Koper: including trains connecting Slovenia directly with Central and Eastern Europe, as shown on Figure 9.

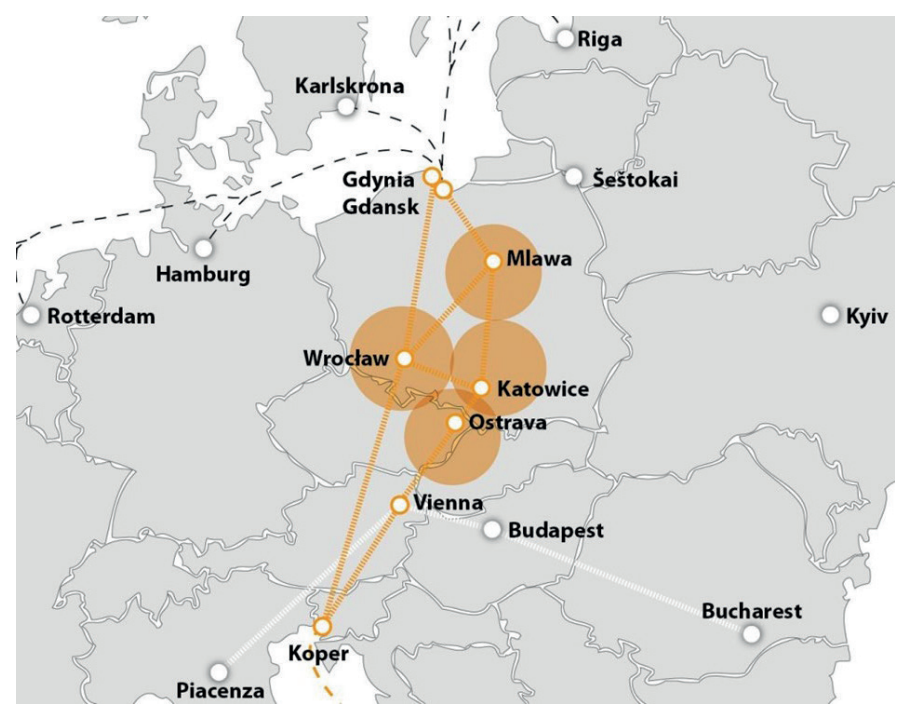

Figure 9. Main railway connections between Poland and Slovenia

Source: Baltic Rail

Next to frequent direct trains, there are daily freight services running to the Ljubljana Zalog station, where goods are loaded onto international trains. Customs formalities can be handled at the stations Koper tovorna and Koper Luka, and there are also two separate servicing tracks at Koper tovorna minor wagon repairs. The rail service Sava Express offers high-quality transport of wagonloads in conventional and combined transports in regular direct trains between Slovenia and Serbia and in the opposite direction. Via Ljubljana Zalog and Belgrade, the new product connects goods flows from the countries of Western and Central Europe with transit transports through Serbia. The volume of cargo throughput of the Port of Koper has been rising, as shown on Figures 10 and 11, with the biggest rise taking place in containers, general cargo and cars.

To further increase the Port's capacity in crucial sectors Luka Koper has started a series of major investments. Construction works for car garage of a capacity of 6,000 parking spaces, are expected to increase the annual throughput for around 162,000 cars. The construction of the garage will meet the increasing demand of customers for covered storage areas, while increasing the unique storage capacity and improving the internal logistics of car transhipment inside the port area. The new garage shall be built considering specific requirements for electric vehicles logistics. The extension of the container terminal is also underway. The Pier I extension project anticipates the construction of a quayside 98.5 metres long and 34.4 meters wide, as well as the construction of a hinterland area on the pier's southern side with a total size of $24,830 \mathrm{~m} 2$. The length of Pier I on the southern 
side, designated for container handling, will be 695 metres. The whole investment which is expected to be completed in 2021 will result in a container terminal ability to handle at least 1.5 million TEUs annually.

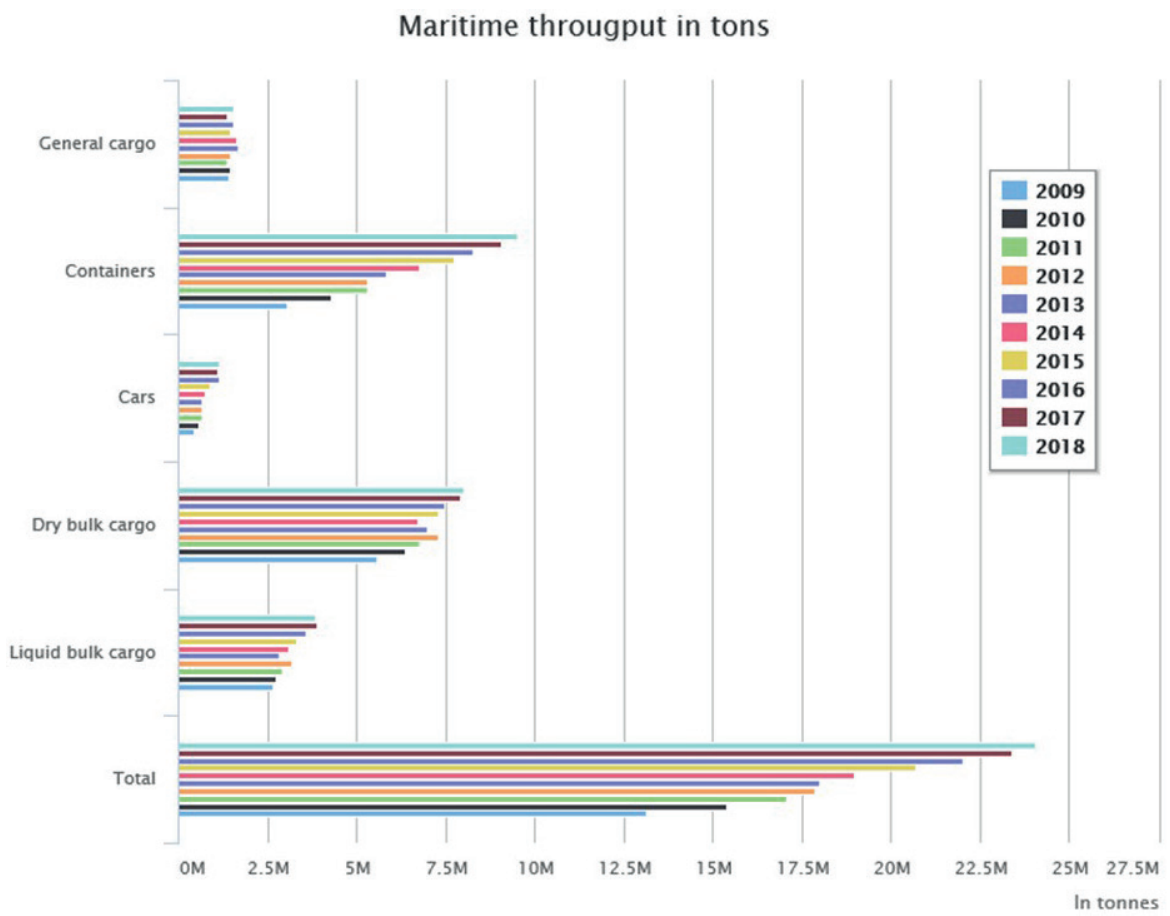

Figure 10. Cargo throughput in the Port of Koper in years 2009-2018 (m tones) Source: Luka-Koper

\section{Maritime throughput history}

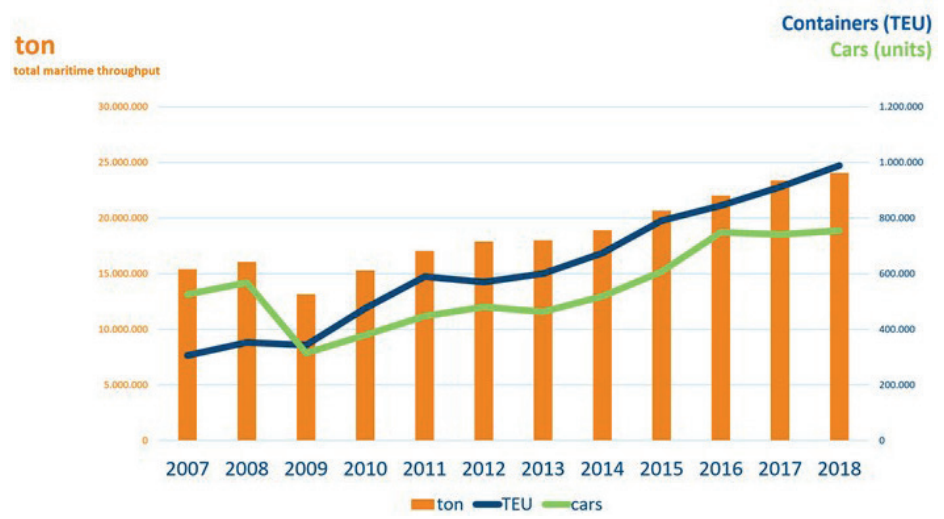

Figure 11. Maritime throughput history in tons, TEUs and car units in years 2007-2018 Source: Luka Koper 
There's also a new RO-RO berth for car-carriers being built. The berth will consist of a series of individual dolphins against which ships can lean, as well as a concrete loading ramp. The surrounding sea bed will be dredged. The new berth will significantly shorten the internal transportation routes, especially those to the warehouses on the right bank of the river Rižana. The new berth is expected to have a positive effect on damage ratio and shall improve quality of loading/unloading operations.

To enhance port's hinterland connectivity, there's a need for new railway connection within the port area. The north-eastern part of the port, where cars are mostly stored, is the only area which lacks access to the railway network. A series of railway tracks that will facilitate the work and speed up loading and unloading of cars from railway wagons is under construction. The project anticipates a construction of four 700-meter-long parallel railway tracks with hydraulic lifting ramps placed at each track's end, permitting the un-/loading of vehicles. The RO-RO berth and the new railway access should be completed in the first quarter of 2020 (Luka Koper, 2019).

The Port of Koper now holds a $40 \%$ share of container traffic in the northern Adriatic and is the largest terminal in the region (Luka Koper, 2019).

\section{Enhancing the efficiency of Baltic-Adriatic Corridor network}

The Baltic-Adriatic Corridor is one of the most important trans-European railway and road axes that runs from North to South, i.e. from Poland through the Czech Republic, Slovakia, Austria to Italy and Slovenia, connecting core Baltic ports in Poland with core ports of the Adriatic Sea in Italy and Slovenia. It runs through the industrialised areas of Southern Poland, Vienna and Bratislava, the Eastern Alpine region and Northern Italy, linking major transport nodes through key rail, road, maritime and air transport connections. It includes around 4,600 km of rail network and 3,600 km of road network as well as 13 urban nodes and airports, 10 ports and 24 rail-road terminals. The corridor also crosses, or runs in parallel, with five other corridors: North-Sea Baltic in Poland, Orient-East Med and Rhine-Danube in the Czech Republic, Austria and Slovakia, Mediterranean in Italy and Slovenia, and Scandinavian-Mediterranean in Italy.

The Port of Gdynia Authority S.A. together with the Polish government presented investment needs in order to meet TEN-T requirements until 2030 and further integrate into the European network. Those investments include, according to the annex C.1 'Projects for the development of the Baltic-Adriatic Corridor in Poland' (European Commission, 2018b) as of 2018:

- Project no 1149 Reconstruction of Kwiatkowski viaduct in Gdynia to the full TEN-T requirements;

- Project no 1150 Via Maris - Construction of north by-pass of Tricity agglomeration (works partly affecting last mile connection to Gdynia port);

- Project no 1167 Via Maris - Droga Czerwona road in Gdynia (from Janka Wiśniewskiego Street to TriCity Bypass/ Morska street junction)/Via Maris;

- Project no 1168 Via Maris - Further integration and modernization of national roads and motorways links with the port's road infrastructure (from Janka Wiśniewskiego Street to the Outer Port in Gdynia). 
Securing a TEN-T last mile accessibility to the maritime port in Gdynia is going to create a European added value by mitigating existing bottlenecks and missing links within the Baltic - Adriatic Corridor, generate positive socio-economic effects on the ports hinterland and enhancing transport services in Gdynia node. The construction of such a strategic investments will meet the TEN-T objectives until 2030.

In Solvenia, EU funds have been used on transport investments aimed to facilitate trade and business operations (European Commission, 2018c):

- e-Mobility infrastructure;

- the redevelopment of the Karavanke road tunnel (second tube);

- building parts of motorways between Beltinci-Lendava, between Maribor and Croatia and Pluska-Hrastje pri Mirni Peči;

- the modernisation of the existing and the construction of the new second railway track of Divača-Koper;

- the nationwide rollout of modern railway wireless communication;

- upgrading the Zidani Most-Celje and the Dolga Gora-Pragersko-Hodoš railway lines;

- the deployment of ERTMS/ETCS on the Dobova-Zidani Most and Pragersko-Maribor-Śentilj railway lines;

- implementing intelligent transport systems to improve cross-border transport;

- deepening the navigation channel and improving maritime accessibility and hinterland connections in the port of Koper;

- developing hybrid electric powertrains for aircrafts;

- the introduction of an electronic tolling system for vehicles above 3.5t using Slovenia's motorway network.

Actions on the corridor are expected to address existing bottlenecks in Slovenian infrastructure to increase land and sea accessibility. Railway investments' priorities concern the removal of the main bottlenecks (particularly in terms of line speed and train length standards), focusing on the most critical cross-border connections, as well as ERTMS deployment. Five Slovenian Actions, receiving over $€ 212$ million of CEF funding, contribute to the overall development of the corridor by improving the main infrastructure parameters. This includes three Actions (both works and studies) on the Divača-Koper railway line of high national importance, including the bottleneck rehabilitation in the area of Bivje and two Actions concerning the second track "Divača-Koper". The remaining two Actions concern the upgrade of Poljčane - Slovenska Bistrica and the Zidani Most - Celje railway railway lines (European Commission, 2018d).

\section{Conclusions}

The most important port infrastructure investments aim to improve ports' connectivity both in terms of marine and hinterland connections and eliminate existing bottlenecks. It is necessary to accommodate a visible growth in international merchandise trade that includes land - to - sea reloading operations. Volumes handled in both Gdynia and Koper Ports have been rising and therefore challenging port facilities capacity and accessibility. Both Poland and Slovenia 
experience a significant growth in maritime international freight transport, which contributes to the general cargo flow in Baltic-Adriatic TEN-T Corridor. Moreover, there is a pressure to increase average and maximum size of vessels handled in ports in order to better use the economies of scale and reduce shipping costs per TEU. Investments directed to lowering shipping costs bring a higher port connectivity, which in consequence contribute to a more competitive marine services offer. For the infrastructure investments in ports to be efficient, they need to be developed along with the specific requirements of contemporary clients:

- the infrastructure allowing for a quality handling of dominating groups of cargo - for example car units and containers in Koper, general cargo in Gdynia;

- increasing safety and security and time-efficiency of port operations - the construction of a second railway track connecting Koper with the hinterland and reconstruction of Kwiatkowski Viaduct in Gdynia;

- reducing bottlenecks and allowing for seamless in and outbound connections. The Adriatic transport route has significantly increased its importance over the last decade, with certain industries leading in the volume of transported cargo. Hinterland connections in the Baltic-Adriatic Corridor are covered by rail and road connections, most of them included and developed in TEN-T network. The corridor offers transit time-wise connections on routes from Scandinavia on the North to numerous destinations via Koper: in Asia, Africa, Turkey, Israel, Egypt, Saudi Arabia and Persian Gulf. Global logistics and shipping companies have recognized the benefits of Adriatic ports for servicing the Central European market.

\section{References}

UNCTAD (2019a) Port liner shipping connectivity index, annual. https://unctadstat.unctad. org/wds/TableViewer/tableView.aspx?ReportId =170026

[Accessed 11 ${ }^{\text {th }}$ Oct. 2019]

UNCTAD (2019b) Maritime Country Profile, https:/unctadstat.unctad.org/CountryProfile/ en-GB/index.html [Accessed 5.11.2019]

European Commission (2011), White Paper "Roadmap to a Single European transport Area -Towards a competitive and resources efficient transport system https://ec.europa.eu/ transport/sites/transport/files/themes/strategies/doc/2011_white_paper/white-paper-illustrated-brochure_en.pdf [Accessed 29.09.2019]

Regulation (EU) No 1315/2013 of the European Parliament and of the Council of 11 December 2013 on Union guidelines for the development of the trans-European transport network and repealing Decision No 661/2010/EU https:/op.europa.eu/en/publication-detail/-/ publication/58c00e4e-b59c-4b64-ad83-3d1a02b33fe8/language-en [Accessed 20.09.2019]

European Comission (2014), Port. Gateways for the Trans European Transport Network 2030 ttps://ec.europa.eu/transport/sites/transport/files/modes/maritime/ports/doc/201404-29-brochure-ports.pdf [Accessed 20.11.2019]

European Commission (2018a) Motorways of the Seas. Detailed Implementation Plan of the European Coordinator, DG Move, https://ec.europa.eu/transport/sites/transport/ files/101_web_final_ii_mos_dip_2018_0.pdf [Accessed 19.11.2019]

Merk O, Notteboom T, Port Hinterland Connectivity, Discussion Paper 12, International Transport Forum, OECD, 2015. https://ideas.repec.org/s/oec/itfaab.html [Accessed 15.11.2019]

European Commission (2015), Report of the exchange of views between ports CEOs and Transport Commissioner Bulc, https://ec.europa.eu/transport/sites/transport/files/ 
modes/maritime/ports/doc/2015-01-19-report-exchange-of-views-comm-bulc-ports-ceos. pdf [Accessed 19.11.2019]

European Parliament (2008), The Evolving Role of EU Seaports in Global Maritime Logistics - Capacities, Challenges and Strategies, European Parliament, Policy Department B, Structural and Cohesion Policies. file://C:/Users/ssile/AppData/Local/Packages/Microsoft. MicrosoftEdge_8wekyb3d8bbwe/TempState/Downloads/BA3008765ENC.en\%20(1).pdf [Accessed 20.11.2019]

ESPO (2019), PRIORITIES OF EUROPEAN PORTS FOR 2019-2024 What ports do for Europe What Europe do for ports Memorandum of the European Sea Ports Organisation for the new Commission and European Parliament, https://www.espo.be/media/Memorandum\%20ESPO \% 20FINAL\% 20Digital\%20version.pdf, [Accessed 20.11.2019]

TENTacle project, (2019a), Pilot action plan: Gdynia CNC urban/transport node, www. tentacle.eu/aktuellt/visa/reports-gdynia-urban-transport-cnc-node2 [Accessed 20.10.2019]

TENTacle project, (2019b), The last mile study for the Gdynia TEN- T core network transport node, corresponding to the investments coherent with the Baltic-Adriatic Corridor Work Plan, WYG International, www.tentacle.eu/aktuellt/visa/reports-gdynia-urban-transportcnc-node2 [Accessed 20.10.2019]

European Commission (2018b) Baltic - Adriatic Third Work Plan of the European Coordinator Kurt Bodewig, DG Move, Brussels, 2018. https://ec.europa.eu/transport/sites/transport/ files/3rd_bac_work_plan__final_webversion.pdf [Accessed 15.11.2019]

NIK (2018), Informacja o wynikach kontroli, Infrastruktura dostępowa do portów morskich, https://www.nik.gov.pl/kontrole/P/17/033/KIN/ [Accessed 10.11.2019]

Luka Koper (2019), Construction works for the garage has started,https://luka-kp.si/eng/ news/single/construction-works-for-garage-started-32447 [Accessed 20.11.2019]

European Commission (2018c), EU Investment in Transport in Slovenia, https://ec.europa.eu/ transport/sites/transport/files/infograph-eu-investment-in-transport-in-slovenia_en.pdf [Accessed 10.11.2019]

European Commission (2018d), CEF support to Baltic-Adriatic Corridor https://ec.europa. eu/inea/sites/inea/files/201803_corridor_report_baltic_adriatic_withcover_0.pdf [Accessed 5.10.2019]

European Commission (2019), Investing in European networks. Five years supporting European infrastructure, https://ec.europa.eu/inea/sites/inea/files/cefpub/cef_implementation_brochure_web_final.pd [Accessed 12.11.2019]

Luka-Koper, Port of Koper, https://luka-kp.si/eng/cargo-statistics [Accessed 10.11.2019]

\section{Corresponding author}

Dorota Książkiewicz can be contacted at: d.ksiazkiewicz@ug.edu.pl Michał Tuszyński can be contacted at: michal_tuszynski@o2.pl 